\title{
SISTEM PAKAR MENDIAGNOSIS KERUSAKAN MESIN DIE CASTING 350 TON DENGAN METODE FUZZY LOGIC BERBASIS WEB
}

\author{
${ }^{1}$ Karyanto, ${ }^{2}$ Arif Budimansyah Purba, ${ }^{3}$ Yessy Yanitasari \\ STMIK Kharisma Karawang \\ E-mail : ${ }^{1}$ karyantochn@gmail.com, ${ }^{2}$ arifbudimansyahpurba@gmail.com, ${ }^{3}$ yanitasari@yahoo.com
}

\begin{abstract}
Abstrak
Kasus kerusakan mesin die casting 350 ton merupakan kasus yang memerlukan bantuan seorang pakar (teknisi) dalam menyelesaikan masalah dengan mengandalkan pengetahuan yang dimilikinya, tetapi kendala yang sering dialami apabila mengandalkan jasa seorang pakar adalah biaya yang harus dikeluarkan relatif tidak sedikit dan juga seorang pakar tidak akan selalu ada di tempat untuk melayani client setiap saat, Pada Penelitian ini dibuat perangkat lunak untuk mengatasi kasus tersebut, dimana perangkat lunak yang dimaksud adalah sistem pakar untuk mendiagnosis kerusakan mesin die casting 350 ton yang di desain untuk memodelkan/mengemulasi kemampuan seorang pakar dalam memecahkan suatu masalah yang berbasiskan pada pengetahuan pakar itu sendiri. Pemrograman yang digunakan dalam pembangunan sistem pakar ini menggunakan metode fuzzy logic berbasis Web. dibuat menggunakan bahasa pemrograman PHP, Object-Oriented Programming (OOP), SDLC Waterfall dan basis data yang digunakan adalah MySQL yang akan dilakukan pada sistem operasi Linux.
\end{abstract}

Kata Kunci: Fuzzy logic, Web, Object-Oriented Programming (OOP), MySQL, Mesin die casting 350 ton, SDLC Waterfall

\section{Abstract}

The case of damage to a die casting machine of 350 tons is a case that requires the help of an expert (technician) in solving problems by relying on their knowledge, but the obstacles often experienced when relying on the services of an expert is the cost to be incurred relatively few and also an expert will not be always be available to serve the client at any time, in this research made software to cope with such cases, in which the software in question is an expert system for diagnosing damage to a die casting machine 350 tons, designed to simulate / emulate the ability of an expert in solving a problem based on expert knowledge itself. Programming used in this expert system development using Webbased fuzzy logic. created using PHP programming language, Object-Oriented Programming (OOP), SDLC Waterfall and database used is MySQL to be done on the Linux operating system.

Keywords: Fuzzy logic, Web, Object-Oriented Programming (OOP), MySQL. die casting machine of 350 tons SDLC Waterfall 


\section{PENDAHULUAN}

Sistem pakar merupakan sistem berbasis komputer yang menggunakan pengetahuan, fakta dan tehnik penalaran dalam memecahkan masalah yang biasanya hanya dapat dipecahkan oleh seorang pakar. Sistem pakar juga merupakan sistem yang menggunakan pengetahuan manusia yang dimasukan ke dalam komputer untuk memecahkan masalahmasalah yang biasanya diselesaikan oleh seorang pakar. Tujuan pengembangan Sistem pakar sebenarnya bukan untuk mengantikan peran manusia tetapi untuk mensubtutisikan pengetahuan manusia kedalam bentuk sistem, sehingga dapat digunakan oleh orang banyak. Die casting merupakan sebuah proses manufaktur untuk memproduksi benda dengan keakuratan, dimensi yang tinggi melalui logam cair (molten metal) yang diinjeksi dengan gaya tekan sehingga logam cair tersebut masuk kedalam cetakan yang disebut dengan die/mold dan kemudian dibiarkan membeku. Saat ini die casting digunakan untuk memproduksi barang-barang yang memiliki keseragaman dan keakuratan dengan jumlah yang tidak terbatas.

Die casting ini juga merupakan salah satu proses manufaktur yang menghasilkan produksi tinggi sehingga dapat mengurangi biaya produksi. Die casting umumnya digunakan untuk memproduksi barang-barang dengan material non ferrous dan paduan (alloy) seperti aluminium, magnesium, zinc (seng), copper (tembaga) dan kuningan (brass). Berdasarkan besarnya tekanan die casting dibedakan menjadi dua jenis yaitu low pressure die casting (LPDC) dan high pressure die casting (HPDC).Low pressure die casting merupakan jenis die casting yang menggunakan tekanan rendah dalam proses pengecorannya. High Pressure Die Casting (HPDC) adalah proses pemasukan (injection) logam cair(molten metal) ke dalam mold cavity dengan tekanan tinggi yang mencapai 250 MPa. PT. Chemco Harapan Nusantara sebuah perusahaan manufacture yang berada di Kawasan Industri Mitra Karawang, Di PT. Chemco itu sendiri dibagi menjadi beberapa Departemen yang diberi tugas sesuai dengan
Pekerjaan yang dihasilkan. Di Departement casting factory 1 terdapat aktiva tetap berupa mesin die casting yang berjumlah 39 unit, untuk kelancaran mesin die casting supaya bisa digunakan untuk berproduksi maka di buat seksi maintenance yang bertanggung jawab atas kerusakan dan perbaikan mesin die casting 350 ton.

Sistem pakar ini akan menggunakan metode logika fuzzy. Keuntungan yang didapat dari penerapan logika fuzzy didalam sistem pakar adalah pengambilan keputusan, sistem pakar dan logika fuzzy merupakan metodologi yang handal dan dapat menarik bagi para praktisi dan analisis. Membahas tentang penggunaan Cooling pada proses percetakan pada mesin die casting. Logika fuzzy digunakan dalam sistem pakar dikarenakan metode ini merupakan metode yang kuat untuk menyelesaikan suatu masalah representasi pengetahuan dilingkungan yang tidak pasti dan ambigu, sehingga metode logika fuzzy merupakan metode yang sangat baik untuk diterapkan didalam sebuah sistem pakar, terlebih lagi metode ini telah sukses untuk memberikan keuntungan-keuntungan pada saat diterapkan dalam berbagai bidang Berdasarkan masalah-masalah yang ada, maka kami akan mencoba meneliti dan, menganalisis sistem yang berjalan. Dengan menggunakan metode SDLC Waterfall berbasis web. Kami membuat judul dalam penelitian ini yaitu "sistem pakar mendiagnosis kerusakan mesin die casting 350 ton dengan metode fuzzy logic berbasis web", dengan menggunakan bahasa pemrograman PHP, OOP sedangkan basis data yang digunakan adalah MySQL yang akan dilakukan pada perangkat keras PC (personal computer) dengan sistem operasi Linux.

\section{TINJAUAN PUSTAKA}

\section{Penelitian Yang Terkait}

Penelitian sebelumnya "Fuzzy logic Based Intellegent Controller Design for an Injection Mould Machine Proses Control" (Santi Prabbha dkk, 2011), membahas tentang temperature suhu injection. Penelitian sebelumnya "Analisa Simulasi High Pressure 
Die Casting (HPDC) Aluminium Alloy dengan dua Varian Cooling Menggunakan Software Magma" (Sulatin, dkk, 2014). Membahas tentang penggunaan Cooling pada proses percetakan pada mesin die casting. Logika fuzzy digunakan dalam sistem pakar dikarenakan metode ini merupakan metode yang kuat untuk menyelesaikan masalah representasi pengetahuan dilingkungan yang tidak pasti dan ambigu, sehingga metode logika fuzzy merupakan metode yang sangat baik untuk diterapkan didalam sebuah sistem pakar. Terlebih lagi metode ini telah sukses untuk memberikan keuntungan-keuntungan pada saat diterapkan dalam berbagai bidang (Djam dan Kimbi, 2011).

\section{Defenisi Sistem Pakar}

Sistem pakar yaitu sistem komputer yang berbasis pada pengetahuan yang terpadu didalam suatu sistem informasi dasar yang ada, sehingga sehingga memiliki kemampuan untuk menyelesaikan masalah dalam bidang tertentu secara cerdas dan efektif, sebagaimana layaknya seorang pakar. Penerapan sistem pakar dimulai dibidang kedokteran untuk keperluan diagnositik para pasien dan juga saat ini sudah di mulai dalam skala kecil di bidang industri dan manajemen, namun demikian sistem pakar baru dikenal luas pada tahun 1987 (Marimin, 2009), sistem pakar adalah perangkat lunak komputer cerdas yang menggunakan pengetahuan dan prosedur inferensi untuk memecahkan masalah yang cukup rumit atau memerlukan kemampuan untuk memecahkannya.

\section{Defenisi Fuzzy Logic}

Fuzzy Logic pertama kali diperkenalkan oleh (Lotfi A. Zadeh, 1965) Dasar fuzzy logic adalah teori himpunan fuzzy. Pada teori himpunan fuzzy, peranan derajat keanggotaan sebagai penentu keberadaan elemen dalam suatu himpunan sangatlah penting. Nilai keanggotaan atau derajat keanggotaan atau membership function menjadi ciri utama dari penalaran dengan fuzzy logic tersebut (Kusumadewi dan Purnomo, 2010). Fuzzy Logic dapat diangggap sebagai kotak hitam yang menghubungkan antara ruang input dengan ruang output. Kotak hitam tersebut berisi cara atau metode yang dapat digunakan untuk mengolah data input menjadi output dalam bentuk informasi yang baik.

\section{METODE PENELITIAN}

Metode penelitian yang digunakan dalam membangun sistem adalah metode SDLCWaterfall, yaitu suatu metodologi pengembangan perangkat lunak yang mengusulkan pendekatan kepada perangkat lunak sistematik dan sekuensial yang mulai pada Project planning phase, Analysis phase, Design phase,Implementation phase, dan Support Phase.

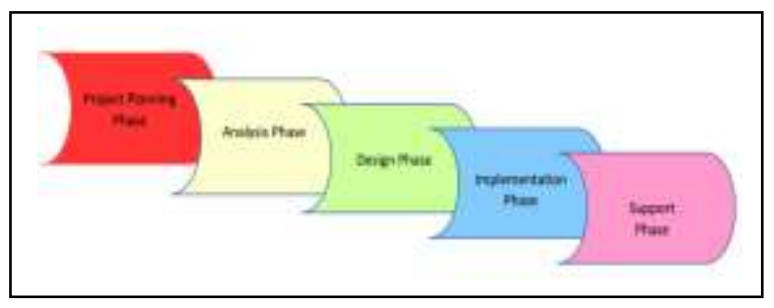

Gambar 1. System Development Live Cycle

\section{Project Planing Phase}

a. Identifikasi Masalah

Menentukan masalah-masalah yang timbul mengenai kerusakan mesin die casting 350 ton.

b. Pengumpulan Data

Melakukan studi literatur melalui jurnaljurnal penelitian dan melakukan proses wawancara dengan seorang pakar.

c. Menganalisis Teori

Menganalisis sistem pakar mendiagnosis kerusakan mesin die casting 350 ton dengan metode fuzzy logic berbasis web.

d. Pembuatan Jadwal Membuat jadwal dan target penelitian.

e. Mencari Solusi

Menentukan system pakar mendiagnosis kerusakan mesin die casting 350 ton dengan metode fuzzy logic berbasis web.

f. Mendefinisikan Kebutuhan

Menentukan tools yang dibutuhkan baik hardware maupun software untuk membangun aplikasi. 


\section{Analysis Phase}

2.1 Analysis Teori Sistem Pakar Fuzzy Logic Tsukamoto

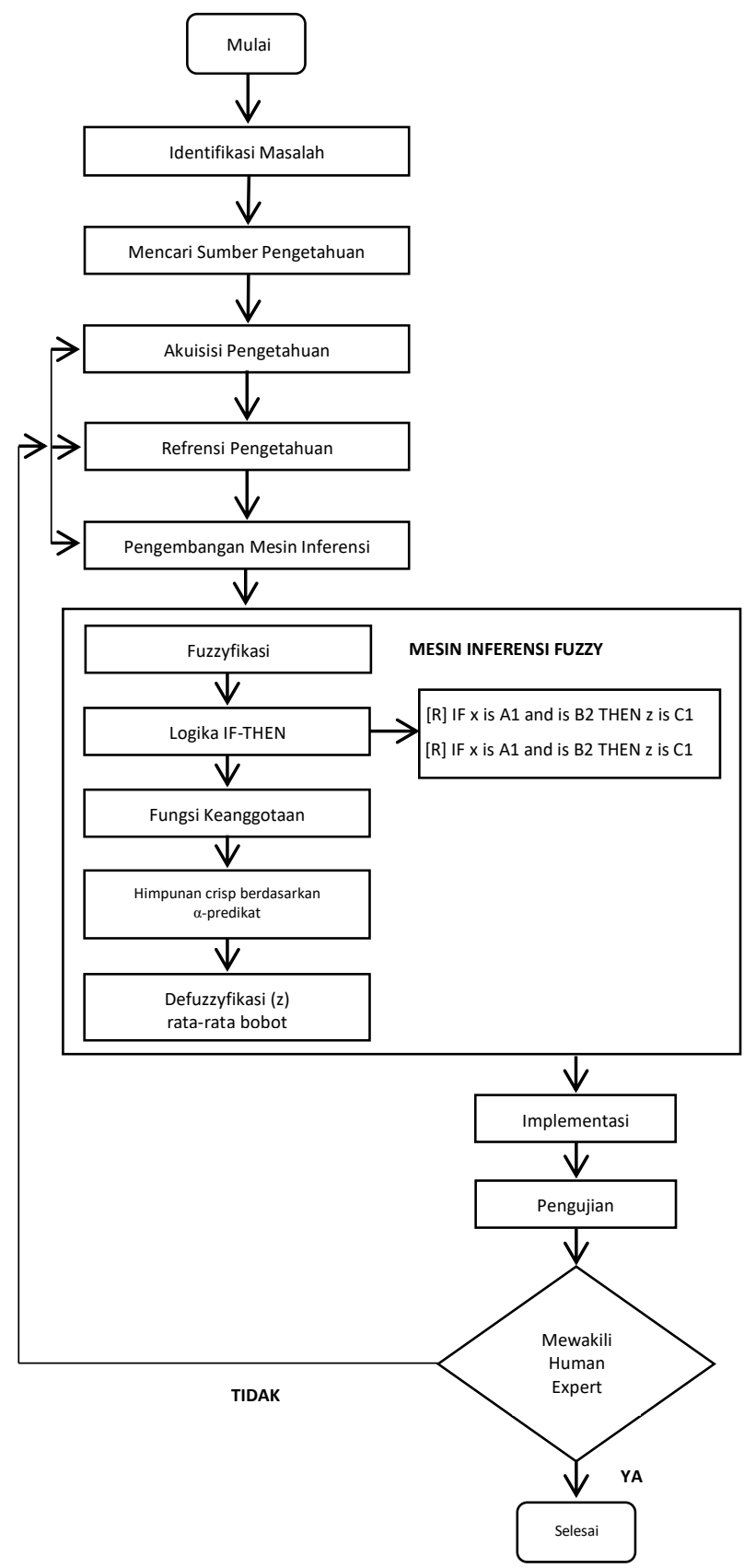

Gambar 2. Flowchart Analisis Fuzzy Logic Tsukamoto

\subsection{Analysis Sistem}

Selain tahapan diatas, juga akan mempelajari sistem yang ada dan menganalisis bidang masalah dengan menggunakan Object Oriented Analysis (OOA).
Hasil dari tahapan ini adalah tujuan perbaikan sistem terhadap masalah serta manfaat yang akan diperoleh. Tahapan analisis meliputi :

1. System activities (Actor Description and Use Case Description, Use Case Diagram, Scenario Use Case).

2. Class diagram (class definition ,class relation).

3. Object interaction (sequence diagram).

4. Object behavior (activity diagram).

\section{Design Phase}

Dalam tahapan ini desain yang dilakukan oleh peneliti adalah pendesainan berbasis Object Oriented Design (OOD) terdiri dari :

1. Desain Proses.

2. Desain Antar Muka.

3. Desain Basis Data

\section{Implementation Phase}

Tahapan implementasi merupakan tahap pembuatan program. Pada Tahapan ini dilakukan beberapa tahapan, antara lain :

1. Instalasi Sistem

Menjelaskan tahapan tahapan dilakukannya proses instalasi aplikasi dalam emulator dan smartphone.

2. Pengujian Terhadap Sistem

Pengujian sistem dilakukan dengan dua tahap yaitu pengujian white box dan black box.

\section{Support Phase}

Setelah sistem yang penulis bangun selesai, langkah terakhir yang dilakukan adalah memperbaiki dan meningkatkan sistem secara berkala.

\section{HASIL DAN PEMBAHASAN}

\section{Project Planing Phase}

Adapun hasil dari tahapan ini adalah berikut :

a. Identifikasi Masalah

Aplikasi sistem pakar fuzzy logic mendiagnosis kerusakan mesin die casting 350 ton untuk membantu maintenance mendiagnosis kerusakan.

b. Pengumpulan Data

Hasil wawancara (lampiran), data data kerusakan mesin die casting 350 ton yang 
pernah terjadi, definisi, solusi, dari kerusakan tersebut.

c. Menganalisis Teori

Hasil Penggunaan algoritme fuzzy logic dan SDLC waterfall diimplementasikan ke dalam aplikasi.

d. Pembuatan Jadwal

Penelitian dilakukan di PT.Chemco Harapan Nusantara plant II Karawang dari febuarijuni 2016 untuk mendiagnosis kerusakan mesin die casting 350 ton.

e. Mencari Solusi

Dapat mendiagnosis kerusakan mesin die casting 350 ton dengan fuzzy logic.

f. Mendefiniskan Kebutuhan

Pengunaan hardware berupa laptop dan printer, untuk softwarenya menggunakan Linux Ubuntu 10.0432 bit, Dia Diagram, Libre Office 3.2.0, geany, Apache dan MySQL.

\section{Analysis Phase}

\subsection{Identifikasi Masalah}

Tabel 1. Masalah Kerusakan Mesin Die Casting 350 ton

\begin{tabular}{|c|c|c|}
\hline $\begin{array}{l}\text { Aturan } \\
\text { Keterangan }\end{array}$ & Diagnosis & Ket. \\
\hline Aturan 1 if & $\begin{array}{l}\text { Ladle tidak bisa mengambil } \\
\text { alumunium. }\end{array}$ & Ya \\
\hline & $\begin{array}{l}\text { Apakah Rantai landle } \\
\text { putus. }\end{array}$ & Ya \\
\hline & Rantai Iadl & Putus \\
\hline Aturan 2 if & $\begin{array}{l}\text { Ladle tidak bisa mengambil } \\
\text { alumunium. }\end{array}$ & \\
\hline & Apakah Rantai landle putus. & Tidak \\
\hline & Apakah Bearing macet. & $\mathrm{Ya}$ \\
\hline & Bear & ng Aus \\
\hline Aturan 3 if & $\begin{array}{l}\text { Ladle Mesin die casting } \\
\text { macet. }\end{array}$ & Ya \\
\hline & Apakah Vanbelt putus. & Ya \\
\hline & Vanbe & Putus \\
\hline Aturan 4 if & $\begin{array}{l}\text { Ladle Mesin die casting } \\
\text { macet. }\end{array}$ & \\
\hline & Apakah vanbelt putus. & Tidak \\
\hline & Bear & ig Aus \\
\hline Aturan 5 if & $\begin{array}{l}\text { Spray Mesin die casting } \\
\text { mampet. }\end{array}$ & Ya \\
\hline & $\begin{array}{l}\text { Apakah } \quad \text { Pipe Spray } \\
\text { mampet. } \\
\text { Pipa spray kotor }\end{array}$ & Ya \\
\hline
\end{tabular}

Pipa Spray Kotor
Aturan 6 if Spray Mesin die casting350 Ya ton macet.

Apakah Pipa spray mampet. Tidak Pipa Spray Patah

Aturan 7 if Spray tidak bisa turun naik. Ya Apakah Piston cylinder aus. Ya

\section{Piston Cylinder Aus}

Aturan 8 if $\quad$ Spray tidak bisa turun naik. Ya Apakah Piston cylinder aus. Tidak

Piston Cylinder Kotor

Aturan 9 if Injeck tidak bisa maju Ya mundur.

Apakah Motor servo injeck Ya terkunci.

Motor Servo InjeckTterkunci

Aturan 10 if Injeck tidak bisa maju Ya mundur.

Apakah Motor sevo injeck Tidak rusak.

Solenoid Forward Return Rusak

Aturan 11 if Safety door Mesin die Ya casting seret.

Apakah Rel roda rusak.

Roda rusak

Aturan 12 if Safety door Mesin die Ya casting seret.

Rel roda rusak.

Tidak Rel Roda Rusak

Aturan 13 if Preaure pump hidraulik Ya macet.

Apakah Pnenumatic valve Ya rusak.

Pnenumatic Valve Rusak

Aturan 14 if Preaure pump hidraulik Ya macet.

Apakah Pnenumatic valve. Tidak

Pnenumatic Valve Kotor

\subsection{Representasi Pengetahuan}

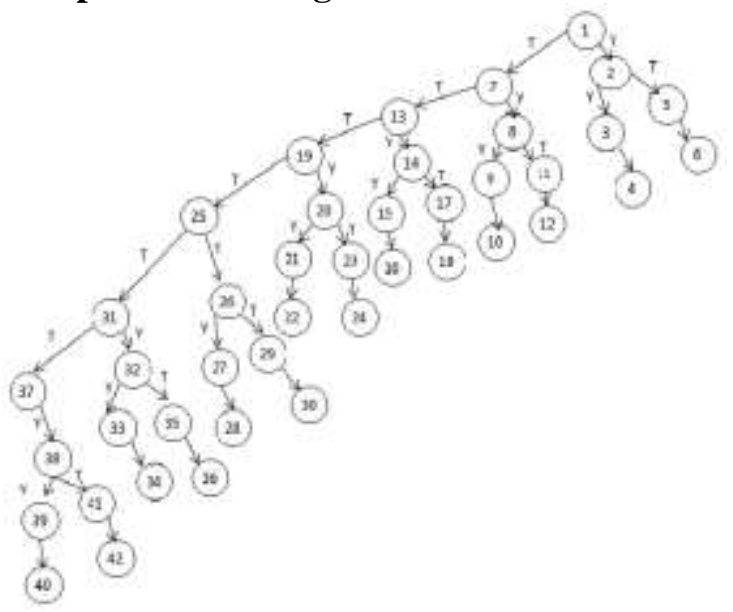

Gambar 3. Pohon Keputusan 


\section{Fuzzifikasi}

Jika Mesin die casting 350 ton akan memproduksi suatu barang maka dipastikan kondisi mesin harus siap untuk berproduksi dengan segala komponen tidak mengalami kerusakan, kondisi komponen mesin die casting 350 ton yang akan mengalami kerusakan bisa dihitung berdasarkan jumlah produksi yang dilakukan, untuk komponen seperti bearing ladle, pnenumatic valve, vanbelt, piston cylinder, seal auto mizer, solenoid forward return, solenoid pnenumatic, roda safety door, rel roda safety door, dalam periode tertentu harus diganti dengan yang baru supaya tetap bekerja secara optimal, berikut data untuk periode waktunya penggantian komponen mesin die casting 350 ton :

Tabel 2. Data Kondisi Lifetime Komponen

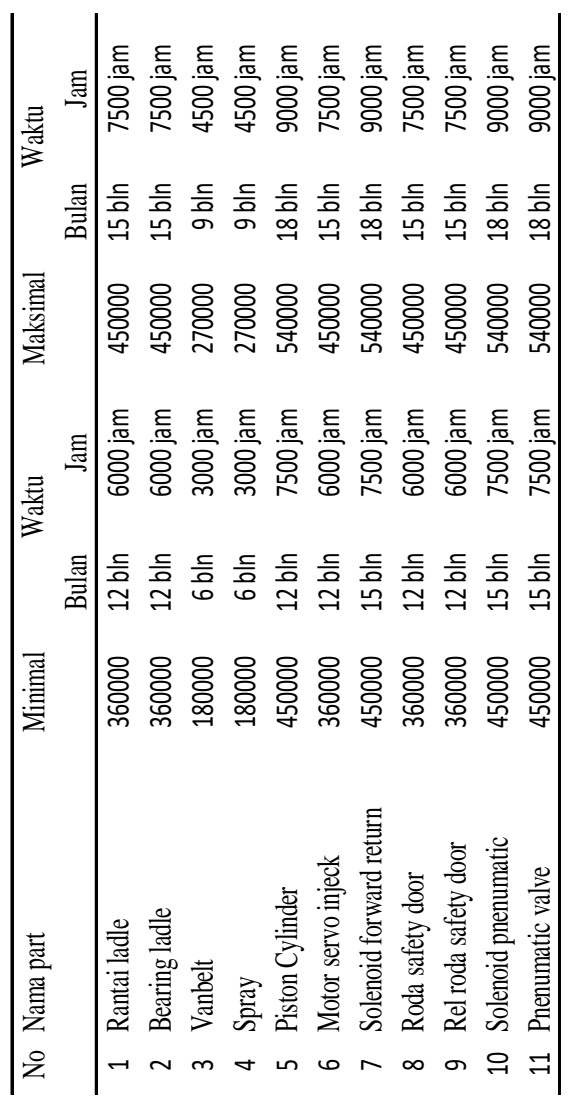

Data Jumlah Satuan :

Maksimal Shot $=540.000$ Shot

Minimal Shot $=180.000$ Shot

Maksimal Bulan $=18$ Bulan

Minimal Bulan $=6$ Bulan

Maksimal Jam $=9.000 \mathrm{Jam}$

Minimal Jam $=3.000 \mathrm{Jam}$

Keterangan :

1. 1 hari dibagi 3 shift, 1 shift 7 jam kerja setiap shift waktu efisien adalah 6 jam 40 menit.

2. 1 shot adalah 1 menit, 1 shift berarti 400 shot produksi.

3. 1 hari $=1200$ shot produksi.

4. 1 bulan adalah 25 hari kerja.

Apabila proses mesin die casting 350 ton memakai 2 aturan fuzzy sebagai berikut :

[R1] IF Maksimal lama And Penggantian lama THEN Jam lama.

[R2] IF Minimal cepat And Penggantian cepat THEN Jam cepat.

\section{A. Rantai Ladle}

Jika maintenance akan mengganti rantai ladle diketahui untuk penggantiannya antara 360.000- 450.000 shot, durasi waktunya 12-15 bulan, sedangkan lamanya jam kerja rantai ladle tersebut 6000 - 7500 jam, jika suatu saat maintenance tersebut akan mengganti pada 390.000 shot pada bulan ke 13, pada jam keberapa rantai ladle tersebut diganti ?.

Data Maksimum dan Minimum

$\begin{array}{ll}\text { Maksimal Shot } & =450.000 \text { Shot } \\ \text { Minimal Shot } & =360.000 \text { Shot } \\ \text { Bulan Tercepat } & =12 \text { Bulan } \\ \text { Bulan Terlama } & =15 \text { Bulan } \\ \text { Jam Tercepat } & =6.000 \mathrm{Jam} \\ \text { Jam Terlama } & =7.500 \mathrm{Jam}\end{array}$

Penyelesaian :

a. Memodelkan Variable Fuzzy (Fuzzyfikasi)

Ada 3 variabel fuzzy yang akan dimodelkan yaitu :

Jumlah shot, Penggantian, Jam kerja. 
1. Rantai ladle, terdiri dari 2 himpunan fuzzy, yaitu Minimal dan Maksimal. Fungsi keanggotaan direpresentasikan :

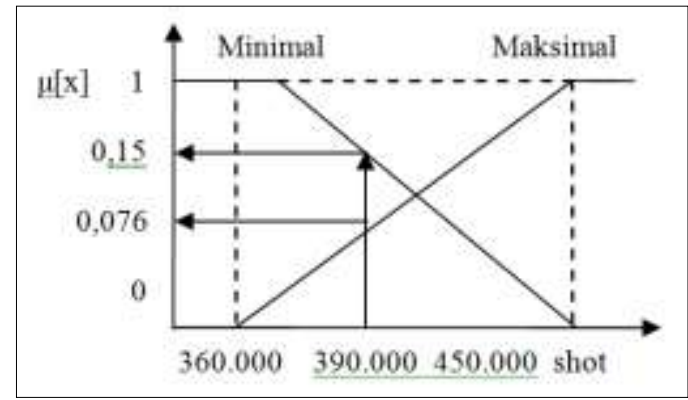

Fungsi keanggotaan himpunan Minimal dan Maksimal dari variable rantai ladle :

$\mu$ Minimal shot $[x]= \begin{cases}1 & ; x \leq 360.000 \\ 450.000-x & ; x \leq 450.000 \\ \hline 390.000 & ; x \geq 450.000 \\ 0 & \end{cases}$

$\mu$ Maximal shot $[x]= \begin{cases}0 & ; x \leq 360.000 \\ \frac{x-360.000}{390.000} & ; 360.000 \leq x \leq 450.000 \\ 1 & ; x \geq 450.000\end{cases}$

Nilai keanggotaan himpunan Minimal dan Maksimal dari variable rantai ladle bisa dicari dengan :

$\mu$ Minimal shot $[390.000]=(450.000-390.000) / 390.000$

$$
=0.15 \text { shot }
$$

$\mu$ Minimal shot $[390.000]=(390.000-360.000) / 390.000$

$$
=0.076 \text { shot }
$$

2. Penggantian terdiri dari 2 himpunan fuzzy yaitu Cepat dan Lama.

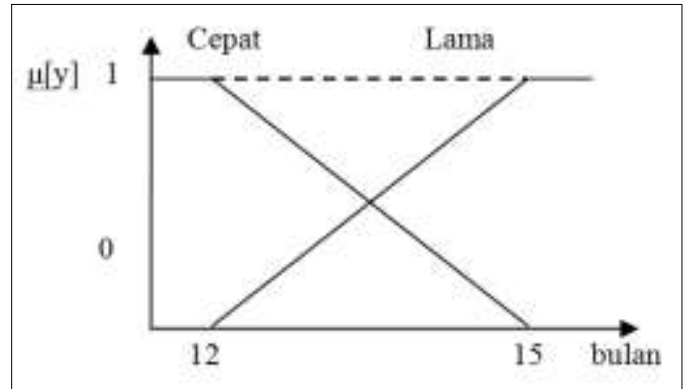

Fungsi keanggotaan himpunan penggantian Cepat dan Lama dari variable Penggantian :

$\mu$ Penggantian Cepat $[y]= \begin{cases}1 & ; y \leq 15 \\ \frac{15-y}{3} & ; 1 \leq y \leq 15 \\ 0 & ; y \geq 150\end{cases}$

$\mu$ Penggantian Lama $[y]= \begin{cases}1 & ; y \leq 15 \\ \frac{y-15}{3} & ; \quad 1 \leq y \leq 15 \\ 1 & y \geq 15\end{cases}$

Nilai keanggotaan himpunan cepat dan lama variable

Penggantian bisa dicari dengan :

$$
\begin{aligned}
\mu \text { Penggantian Cepat [13] } & =(15-13) / 3 \\
& =0.666 \text { Bulan } \\
\mu \text { Penggantian Lama [13] } & =(15-12) / 3 \\
& =1 \text { Bulan }
\end{aligned}
$$

3. Jam terdiri dari 2 himpunan fuzzy yaitu Cepat dan Lama.

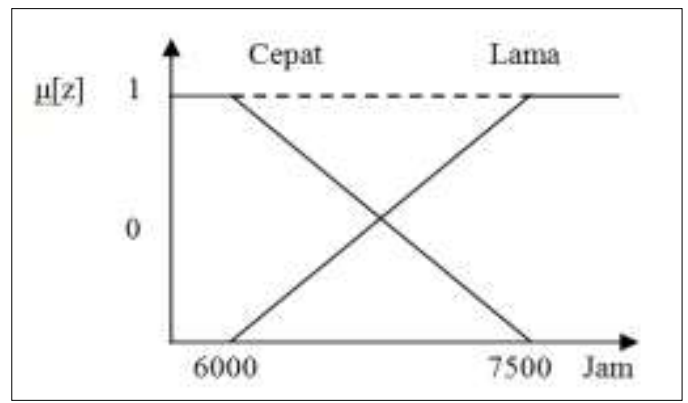

Fungsi keanggotaan himpunan Jam Cepat dan lama dari variable :

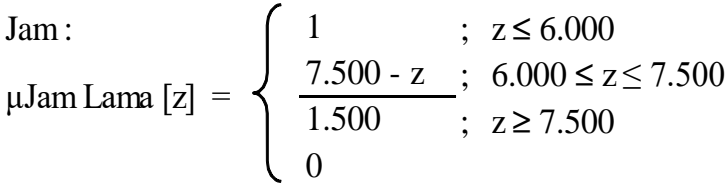

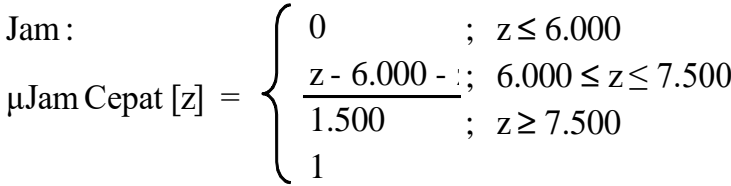




\section{b. Inferensi}

\section{[R1] IF Maksimal Lama AND Pengantian Lama THEN Jam Lama}

Nilai keanggotaan antarseden untuk aturan fuzzy [R1] yang dinotasikan dengan $\alpha 1$ diperoleh dengan rumus sebagai berikut :

$$
\begin{aligned}
\alpha 1 & =\mu \text { Maksimal Lama Penggantian Lama } \\
& =\operatorname{Max}(\mu \text { Maksimal Lama [390.000], } \mu \text { Penggantian Lama }[13] \\
& =\operatorname{Max}(0.076)(0.66) \\
& =0.66
\end{aligned}
$$

Menurut fungsi keanggotaan himpunan Jam lama dalam aturan fuzzy [R1], Maka nilai z1 adalah :

$$
\begin{aligned}
& \mathrm{z} 1=(7.500-\mathrm{z}) / 1.500=0.66 \\
& \mathrm{z} 1=6.500 \mathrm{Jam}
\end{aligned}
$$

\section{[R2] IF Minimal Cepat AND Pengantian Cepat THEN Jam Cepat}

Nilai keanggotaan antarseden untuk aturan fuzzy [R1] yang dinotasikan dengan $\alpha 2$ diperoleh dengan rumus sebagai berikut :

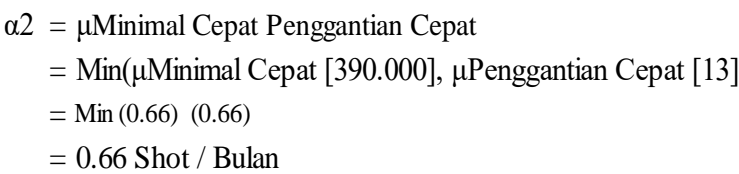

Menurut fungsi keanggotaan himpunan Jam cepat dalam aturan fuzzy [R2], Maka nilai z2 adalah :

$$
\begin{aligned}
& \mathrm{z} 2=7.500-0,66 *(7.500-6.000) \\
& \mathrm{z} 2=6.510 \mathrm{Jam}
\end{aligned}
$$

\section{c. Output Crisp (Deffuzzyfikasi)}

Pada metode Tsukamoto, untuk menentukan output crisp digunakan defuzzyfikasi rata-rata berbobot, yaitu :

$$
\begin{aligned}
& \mathrm{z}=\frac{\alpha 1 * \mathrm{z} 1+\alpha 2 * \mathrm{z}}{\alpha 1+\alpha 2} \\
& \mathrm{z}=\frac{0.66 * 6.500+0.33 * 6.500}{0.66+0.33} \\
& \mathrm{z}=\frac{4.290+2.14}{0.99} \\
& \mathrm{z}=\frac{6.435}{0.99} \\
& \mathbf{z}=\mathbf{6 . 5 0 0 ~ J a m}
\end{aligned}
$$

\subsection{Analysis System}

a. System Activities (Use Case Diagram)

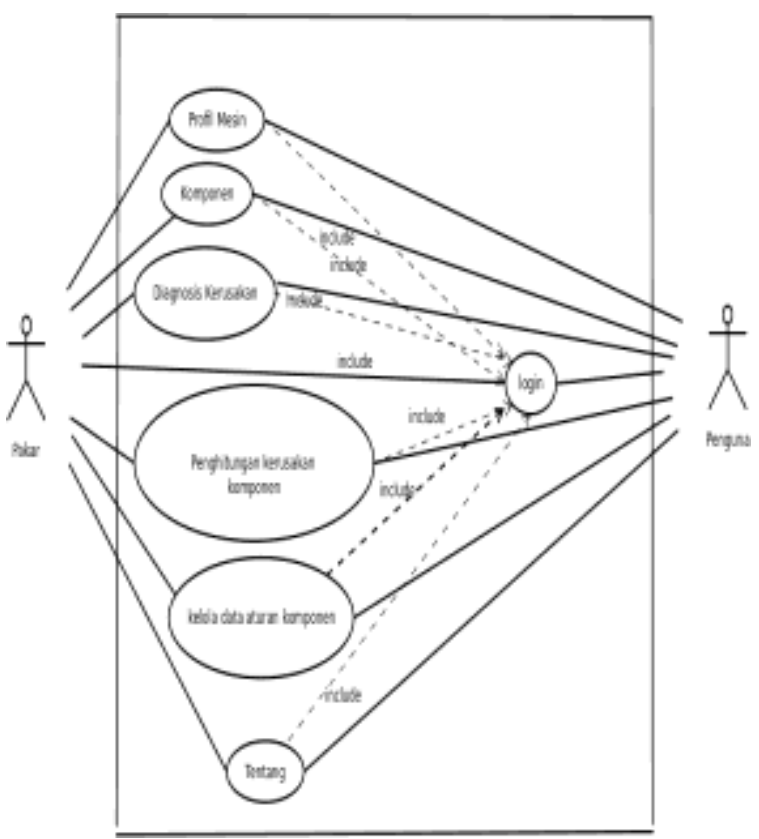

Gambar 4. Use Case Diagram

b. Class Diagram (Class Relation)

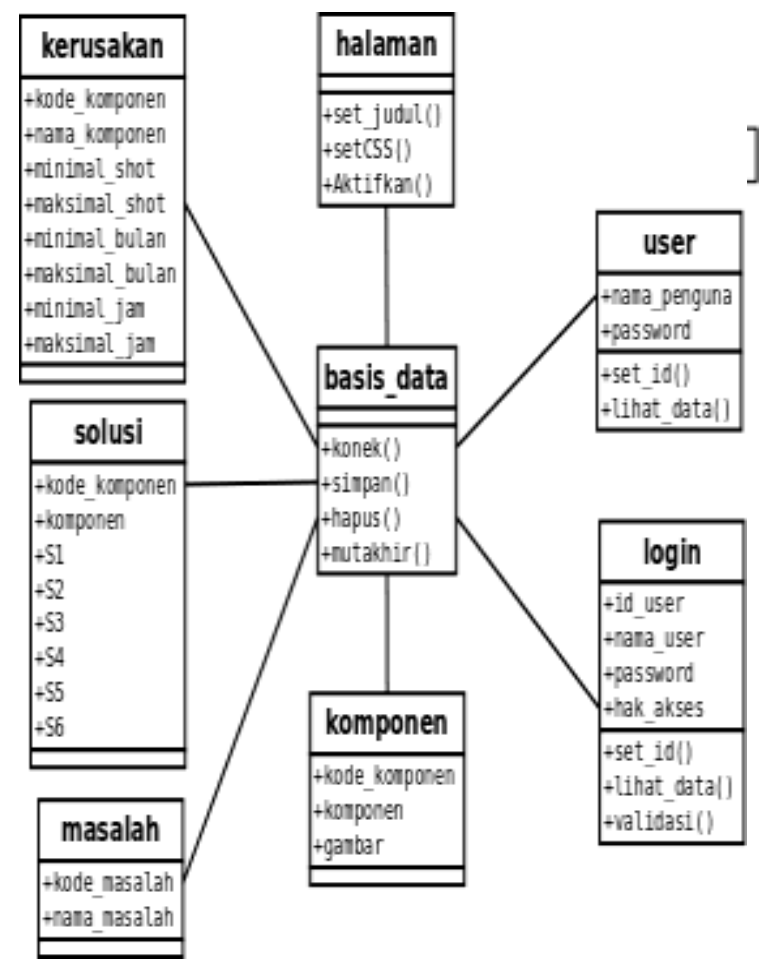

Gambar 5. Sequence Diagram Profil Mesin 


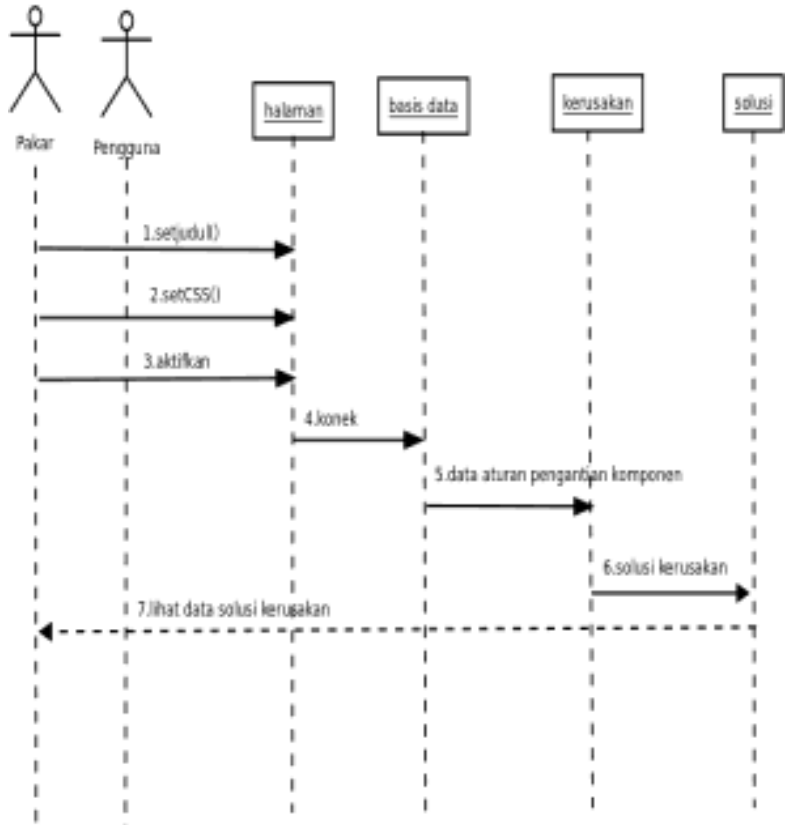

Gambar 6. Sequence Diagram Diagnosis Kerusakan

d. Object behavior (Activity Diagram)

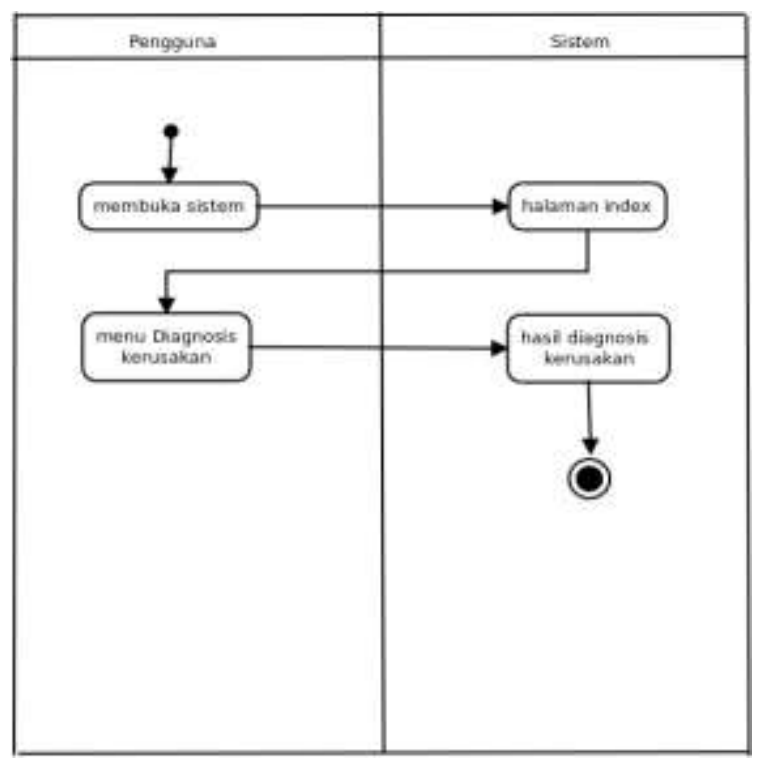

Gambar 7. Activity Diagram Diagnosis Kerusakan

\section{Design Phase}

Berikut ini adalah rancangan desain antar muka sistem :

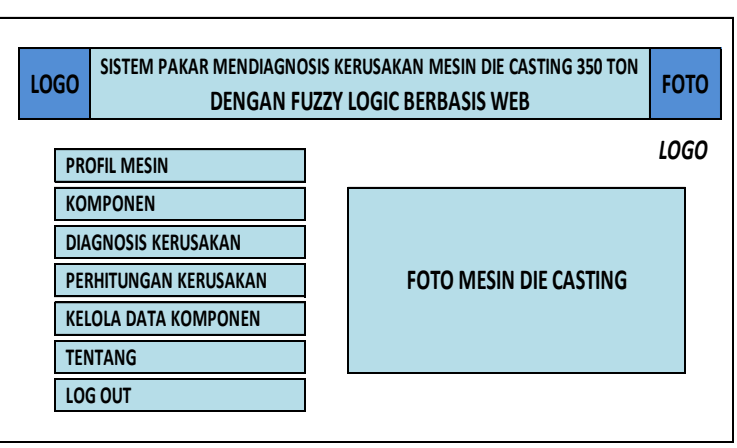

Gambar 8. Desain Antar Muka

\section{Implementation Phase}

\subsection{Implementasi}

Berikut adalah gambar dari sistem yang telah dibuat.

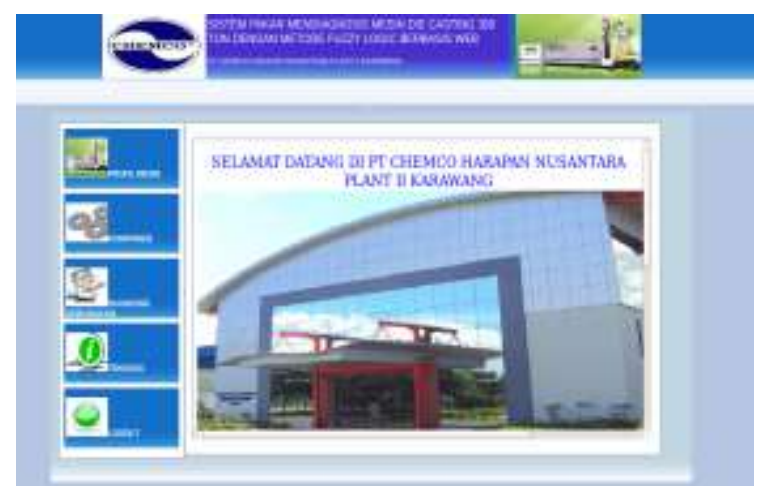

Gambar 9. Halaman Utama Sistem

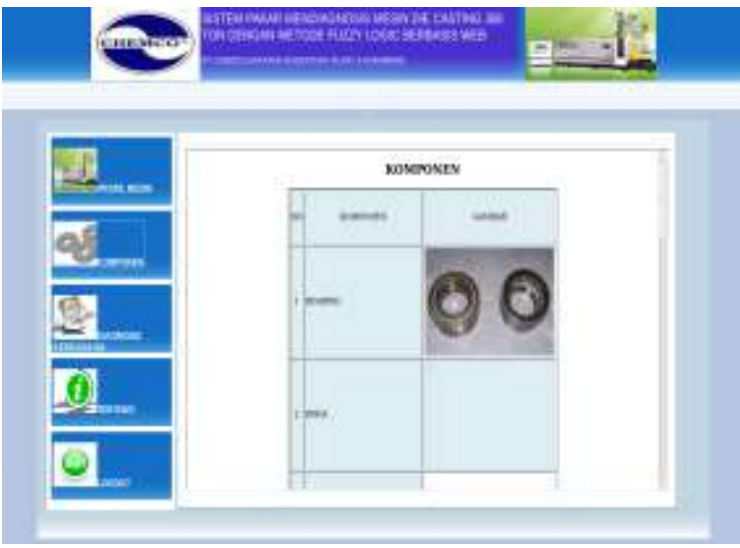

Gambar 10. Komponen 


\section{KESIMPULAN DAN SARAN}

\section{Kesimpulan}

Setelah penulis melakukan analisis, mendesain, dan menyelesaikan pembuatan aplikasi ini maka penulis mendapatkan beberapa kesimpulan sebagai berikut :

1. Sistem pakar mendiagnosis kerusakan mesin die casting 350 ton dengan menggunakan fuzzy logic tsukamoto.

2. Aplikasi ini hanya dapat dijalankan pada sistem operasi linux berbasis web.

3. Ada 14 jenis Kerusakan yang ditampilkan.

4. Diagnosis adalah diagnosis kerusakan mesin die casting 350 ton.

5. Hasil diagnosis berupa hasil pemecahan masalah dari kerusakan mesin die casting 350 ton.

\section{Saran}

Sistem dapat dikembangkan lagi dengan aplikasi mobile phone yang dapat membuat sistem semakin handal dalam proses kerja mesin die casting 350 ton

\section{DAFTAR PUSTAKA}

Kusrini. (2006), Sistem Pakar "Teori dan Aplikasinya", Penerbit Andi. Yogyakarta Arhami, M. (2005). Konsep Dasar Sistem Pakar Andi : Yogyakarta

Jogiyanto, H.M., 2005, Analisis dan Desain Sistem Informasi Andi Offset, Yogyakarta.

Satzinger, John W., Jackson, Robert B., Burd, Stephen D. 2010. System Analysis and Design in a Changing World, Fourth Edition, Thomson Course Technology, Cananda. 